\section{Cureus}

Received 08/23/2018

Review began 08/31/2018

Review ended 09/12/2018

Published 09/18/2018

\section{(c) Copyright 2018}

Pradhan et al. This is an open access article distributed under the terms of the Creative Commons Attribution License CC-BY 3.0., which permits unrestricted use, distribution, and reproduction in any medium, provided the original author and source are credited.

\title{
A Systematic Review of Marijuana Use and Outcomes in Patients with Myocardial Infarction
}

\author{
Ravi R. Pradhan ${ }^{1}$, Shashi R. Pradhan ${ }^{2}$, Shobha Mandal ${ }^{3}$, Dhiri R. Pradhan ${ }^{4}$
}

1. Internal Medicine, Tribhuvan University Institute of Medicine, Kathmandu, NPL 2. Surgery, B.P. Koirala Institute of Health Sciences, Dharan, NPL 3. Internal Medicine, Salem Internal Medicine PC, Pennsville, USA 4. Internal Medicine, Yadukuha Primary Health Care Centre, Janakpur, NPL

$\square$ Corresponding author: Ravi R.Pradhan, drravipradhan@iom.edu.np Disclosures can be found in Additional Information at the end of the article

\section{Abstract}

The prevalence of marijuana use is increasing after its legalization in a few states of the United States (US). Smoking marijuana is found to be associated with an increased risk of myocardial infarction (MI) immediately after its use. However, knowledge about the impact of marijuana on outcomes following MI is limited. In light of the rapidly shifting landscape regarding the legalization of marijuana for medical and recreational purposes, it is necessary to evaluate the impact of marijuana on the outcomes following MI. In this systematic review, we opted to review the effects of marijuana on in-hospital and long-term outcomes following MI.

Categories: Cardiology, Internal Medicine, Psychiatry

Keywords: marijuana, legalization, prevalence, myocardial infarction, outcomes

\section{Introduction And Background}

Laws and attitudes towards marijuana in the United States (US) are becoming more permissive. Marijuana is the most commonly used illicit drug in the US. The prevalence of marijuana use was $4.1 \%$ in 2001-2002 and 9.5\% in 2012-2013 in the US [1]. After its legalization in a few states of the US, its use is becoming increasingly popular over time. Marijuana is found to be beneficial for the treatment of numerous health conditions such as cancer, glaucoma, Human Immunodeficiency Virus (HIV)/Acquired Immunodeficiency Syndrome (AIDS), and posttraumatic stress disorder [2]. The active constituent of marijuana is tetrahydrocannabinol, which is a mixed agonist for cannabinoid 1 and 2 receptors (CB1 and CB2) [3]. The activation of the CB1 receptor may increase lipid resistance and promote chronic cardiovascular dysfunction, particularly in obesity [4] and diabetes [5]. In contrast, the activation of CB2 receptors may suppress the inflammatory response and reduce atherosclerosis progression [6-7].

Marijuana use is found to be associated with adverse cardiovascular events. It increases sympathetic nervous system activity, which ultimately increases the heart rate, supine systolic, and diastolic blood pressures, leading to increased myocardial oxygen demand to a degree that the time to exercise-induced angina in patients with a history of stable angina may be decreased [8]. In addition, marijuana has been associated with triggering myocardial infarction (MI) in young male patients. After smoking marijuana, the risk of MI onset increases by 4.8 fold for the first 60 minutes. The annual risk of MI in a daily cannabis user increases from $1.5 \%$ to $3 \%$ per year [8]. 


\section{Cureus}

In this systematic review, we reviewed the current evidence for the impact of marijuana use on outcomes following MI. The present work is, to our best knowledge, the most comprehensive systematic review of the latest four studies, allowing the direct comparison of the impact of marijuana on outcomes following cardiovascular incidents such as MI.

\section{Review}

\section{Methods}

Search Strategy

The PRISMA statement for reporting systematic reviews recommended by the Cochrane Collaboration was followed for conducting this systematic review (Figure 1). PubMed, Google Scholar, CENTRAL, and EMBASE were searched for peer-reviewed researches published between July 2001 and July 2018. Databases were searched using the search terms under two search themes and combined using the Boolean operator 'AND'. For the theme 'Marijuana', we used text words: marijuana, cannabinoids, and tetrahydrocannabinol. For the theme 'Myocardial Infarction', we used text words: myocardial infarction, acute myocardial infarction, ischemic heart disease, coronary artery disease, MI, AMI, IHD, and CAD.

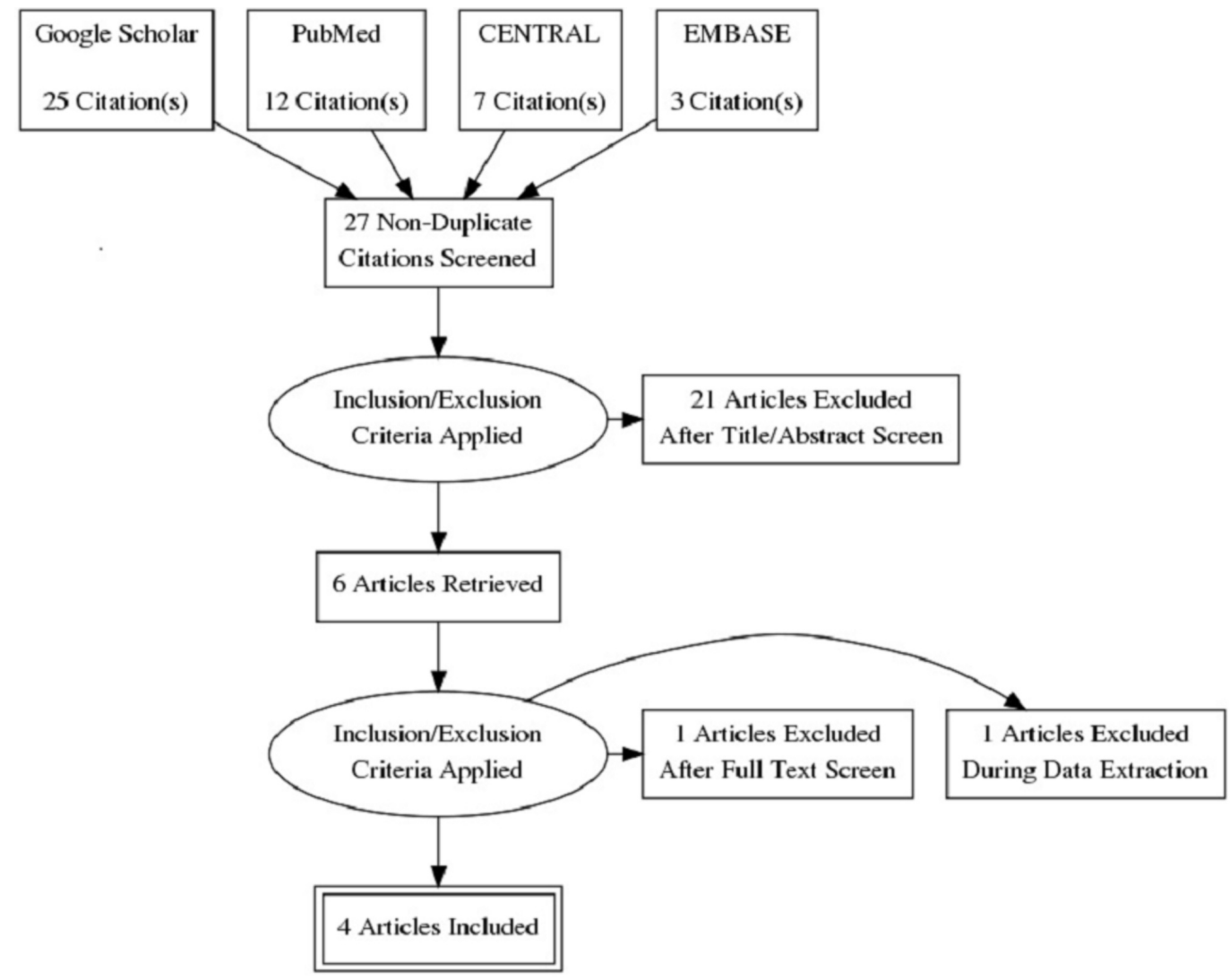

FIGURE 1: PRISMA diagram detailing the study identification and selection process.

PRISMA: preferred reporting items for systematic reviews and meta-analyses

Selection Criteria 
Studies published in the English language were included in the review if they aimed to assess the impact of marijuana use on outcomes following MI. Studies that aimed to assess the impact of marijuana use on the outcomes of other diseases such as cancer, glaucoma, and posttraumatic stress disorder were excluded. In addition, case reports, editorials, and correspondences were also excluded. Diagram detailing the study identification and selection process is given in Figure 1.

\title{
Data Abstraction
}

The authors (RRP, SRP, and SM) screened the articles based on the inclusion and exclusion criteria. Full texts were obtained for articles that met the inclusion criteria. The authors developed a data abstraction spreadsheet using Microsoft Excel version 2013 (Microsoft Corp., Redmond, WA, USA) and included the following information: author, year of publication, journal, country where the study was done, study design, sample size, baseline characteristics of the patients, and outcomes in terms of morbidity and mortality. Any discrepancies were solved by consultation with the fourth author DRP.

\section{Results and discussion}

\author{
Study Characteristics
}

The study's characteristics are represented in Table 1. All the articles included in this review were of good quality, considering the presence of clear objectives, a clearly mentioned study design, and a clearly described statistical analysis. Four studies were included in this systematic review, with a total of 3,729,840 subjects. All the studies have used their own inclusion criteria. Studies conducted by Desai et al. [9] and Johnson-Sasso et al. [10] were retrospective, whereas Frost et al. [11] and Kenneth et al. [12] performed a cohort study, and they followed the patients for 18 and 3.8 years, respectively. All the studies were conducted in the USA. 


\section{Cureus}

\begin{tabular}{|c|c|c|c|c|c|c|c|c|}
\hline Author & Year & Country & Journal & Sample size & $\begin{array}{l}\text { Study } \\
\text { design }\end{array}$ & Inclusion criteria & Primary outcome & Secondary outcome \\
\hline $\begin{array}{l}\text { Desai et } \\
\text { al. [9] }\end{array}$ & 2017 & USA & Cureus & $\begin{array}{l}\text { AMI without } \\
\text { Marijuana: } \\
2,416,162 \\
\text { AMI with } \\
\text { Marijuana: } \\
35,771\end{array}$ & Retrospective & AMI patients aged 11 to 70 years & $\begin{array}{l}\text { Prevalence of AMI; } \\
\text { predictors of AMI } \\
\text { incidence; inpatient } \\
\text { mortality of AMI }\end{array}$ & $\begin{array}{l}\text { Length of hospital } \\
\text { stay; total hospital } \\
\text { charges; } \\
\text { complications of AMI }\end{array}$ \\
\hline $\begin{array}{l}\text { Frost et } \\
\text { al. [11] }\end{array}$ & 2013 & USA & $\begin{array}{l}\text { American } \\
\text { Heart } \\
\text { Journal }\end{array}$ & $\begin{array}{l}\text { AMI without } \\
\text { Marijuana: } \\
1988 \text { AMI } \\
\text { with } \\
\text { Marijuana: } \\
109\end{array}$ & 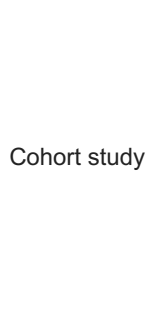 & $\begin{array}{l}\text { Patients with creatine kinase level } \\
\text { above the upper limit of normal, } \\
\text { and positive MB isoenzymes; } \\
\text { identifiable onset of symptoms of } \\
\text { infarction; able to complete a } \\
\text { structured interview }\end{array}$ & $\begin{array}{l}\text { All-cause mortality; } \\
\text { the association } \\
\text { between marijuana } \\
\text { use and the rate of } \\
\text { mortality over up to } \\
18 \text { years of follow- } \\
\text { up }\end{array}$ & NA \\
\hline $\begin{array}{l}\text { Johnson- } \\
\text { Sasso et } \\
\text { al. [10] }\end{array}$ & 2018 & USA & $\begin{array}{l}\text { PLOS } \\
\text { ONE }\end{array}$ & $\begin{array}{l}\text { AMI without } \\
\text { Marijuana: } \\
\text { 1,270,043 } \\
\text { AMI with } \\
\text { Marijuana: } \\
3,854\end{array}$ & Retrospective & AMl patients aged $>18$ to $<70$ years & $\begin{array}{l}\text { Composite of death; } \\
\text { mechanical } \\
\text { ventilation; cardiac } \\
\text { arrest; placement of } \\
\text { an intraaortic } \\
\text { balloon pump } \\
\text { (IABP); Shock }\end{array}$ & $\begin{array}{l}\text { Individual } \\
\text { components of the } \\
\text { primary outcome; } \\
\text { coronary angiogram; } \\
\text { coronary } \\
\text { percutaneous } \\
\text { intervention; STEMI } \\
\text { vs. NSTEMI }\end{array}$ \\
\hline $\begin{array}{l}\text { Kenneth } \\
\text { et al. } \\
{[12]}\end{array}$ & 2008 & USA & $\begin{array}{l}\text { American } \\
\text { Heart } \\
\text { Journal }\end{array}$ & $\begin{array}{l}\text { AMI without } \\
\text { Marijuana: } \\
1861 \text { AMI } \\
\text { with } \\
\text { Marijuana: } \\
52\end{array}$ & Cohort study & $\begin{array}{l}\text { Patients were required to have a } \\
\text { creatine kinase level above the } \\
\text { upper limit of normal; positive MB } \\
\text { isoenzymes; identifiable onset of } \\
\text { symptoms of infarction; ability to } \\
\text { complete a structured interview }\end{array}$ & All-cause mortality & $\begin{array}{l}\text { Cardiovascular and } \\
\text { noncardiovascular } \\
\text { mortality }\end{array}$ \\
\hline
\end{tabular}

\section{TABLE 1: Key methodological characteristics of selected studies}

USA: United States of America; NA: not available; AMI: acute myocardial infarction; IABP: intraaortic balloon pump; STEMI: ST elevation myocardial infarction; NSTEMI: non-ST elevation myocardial infarction

\section{Patient Characteristics}

The patient characteristics of the study are shown in Table 2. In all the studies, marijuana users tended to be younger, male, and current smokers and had less co-morbidity than the non-users. The data about the mean body mass index (BMI) was available only in two studies [11-12]. The mean BMI $\left(\mathrm{Kg} / \mathrm{m}^{2}\right)$ values reported in the study by Frost et al. [11] and Kenneth et al. [12] were $28.3 \pm 5.2$ and $27.3 \pm 5.2$ in the acute myocardial infarction (AMI) without marijuana group and $29.9 \pm 5.6$ and $27.8 \pm 5.3$ in the AMI with marijuana group, respectively. 


\section{Cureus}

\begin{tabular}{|c|c|c|c|c|c|c|c|c|c|}
\hline Study & Mean age \pm SD & Male (\%) & BMI $\left(\mathrm{kg} / \mathrm{m}^{2}\right)$ & $\begin{array}{l}\text { Alcohol } \\
\text { Abuse (\%) }\end{array}$ & $\begin{array}{l}\text { Smoking } \\
(\%)\end{array}$ & $\begin{array}{l}\text { Cocaine } \\
\text { Abuse (\%) }\end{array}$ & $\begin{array}{l}\text { Diabetes } \\
\text { (\%) }\end{array}$ & $\begin{array}{l}\text { Hypertension } \\
\text { (\%) }\end{array}$ & $\begin{array}{l}\text { Dyslipidemia } \\
\text { (\%) }\end{array}$ \\
\hline \multirow{2}{*}{$\begin{array}{l}\text { Desai et } \\
\text { al. [9] }\end{array}$} & $\begin{array}{l}\text { AMI without } \\
\text { Marijuana: } \\
57.79 \pm 8.98\end{array}$ & $\begin{array}{l}\text { AMI without } \\
\text { Marijuana: } \\
66.0\end{array}$ & $\begin{array}{l}\text { AMI without } \\
\text { Marijuana: NA }\end{array}$ & $\begin{array}{l}\text { AMI without } \\
\text { Marijuana: } \\
5.1\end{array}$ & $\begin{array}{l}\text { AMI without } \\
\text { Marijuana: } \\
46.3\end{array}$ & $\begin{array}{l}\text { AMI without } \\
\text { Marijuana: } \\
1.2\end{array}$ & $\begin{array}{l}\text { AMI without } \\
\text { Marijuana: } \\
30.0\end{array}$ & $\begin{array}{l}\text { AMI without } \\
\text { Marijuana: } \\
67.6\end{array}$ & $\begin{array}{l}\text { AMI without } \\
\text { Marijuana: } \\
58.9\end{array}$ \\
\hline & $\begin{array}{l}\text { AMI with } \\
\text { Marijuana: } \\
49.34 \pm 10.80\end{array}$ & $\begin{array}{l}\text { AMI with } \\
\text { Marijuana: } \\
76.9\end{array}$ & $\begin{array}{l}\text { AMI with } \\
\text { Marijuana: NA }\end{array}$ & $\begin{array}{l}\text { AMI with } \\
\text { Marijuana: } \\
22.6\end{array}$ & $\begin{array}{l}\text { AMI with } \\
\text { Marijuana: } \\
75.9\end{array}$ & $\begin{array}{l}\text { AMI with } \\
\text { Marijuana: } \\
18.9\end{array}$ & $\begin{array}{l}\text { AMI with } \\
\text { Marijuana: } \\
18.3\end{array}$ & $\begin{array}{l}\text { AMI with } \\
\text { Marijuana: } \\
58.9\end{array}$ & $\begin{array}{l}\text { AMI with } \\
\text { Marijuana: } \\
50.6\end{array}$ \\
\hline \multirow{2}{*}{$\begin{array}{l}\text { Frost et al. } \\
{[11]}\end{array}$} & $\begin{array}{l}\text { AMI without } \\
\text { Marijuana: } 52.3 \\
\pm 7.7\end{array}$ & $\begin{array}{l}\text { AMI without } \\
\text { Marijuana: } \\
77\end{array}$ & $\begin{array}{l}\text { AMI without } \\
\text { Marijuana: } 28.3 \\
\pm 5.2\end{array}$ & $\begin{array}{l}\text { AMI without } \\
\text { Marijuana: } \\
\text { NA }\end{array}$ & $\begin{array}{l}\text { AMI without } \\
\text { Marijuana: } \\
48\end{array}$ & $\begin{array}{l}\text { AMI without } \\
\text { Marijuana: } \\
1\end{array}$ & $\begin{array}{l}\text { AMI without } \\
\text { Marijuana: } \\
17\end{array}$ & $\begin{array}{l}\text { AMI without } \\
\text { Marijuana: } 37\end{array}$ & $\begin{array}{l}\text { AMI without } \\
\text { Marijuana: } \\
\text { NA }\end{array}$ \\
\hline & $\begin{array}{l}\text { AMI with } \\
\text { Marijuana: } 43.7 \\
\pm 8.2\end{array}$ & $\begin{array}{l}\text { AMI with } \\
\text { Marijuana: } \\
93\end{array}$ & $\begin{array}{l}\text { AMI with } \\
\text { Marijuana: } 29.9 \\
\pm 5.6\end{array}$ & $\begin{array}{l}\text { AMI with } \\
\text { Marijuana: } \\
\text { NA }\end{array}$ & $\begin{array}{l}\text { AMI with } \\
\text { Marijuana: } \\
67\end{array}$ & $\begin{array}{l}\text { AMI with } \\
\text { Marijuana: } \\
16\end{array}$ & $\begin{array}{l}\text { AMI with } \\
\text { Marijuana: } 9\end{array}$ & $\begin{array}{l}\text { AMI with } \\
\text { Marijuana: } 28\end{array}$ & $\begin{array}{l}\text { AMI with } \\
\text { Marijuana: } \\
\text { NA }\end{array}$ \\
\hline \multirow{2}{*}{$\begin{array}{l}\text { Johnson- } \\
\text { Sasso et } \\
\text { al. [10] }\end{array}$} & $\begin{array}{l}\text { AMI without } \\
\text { Marijuana: } 57.2\end{array}$ & $\begin{array}{l}\text { AMI without } \\
\text { Marijuana: } \\
66\end{array}$ & $\begin{array}{l}\text { AMI without } \\
\text { Marijuana: NA }\end{array}$ & $\begin{array}{l}\text { AMI without } \\
\text { Marijuana: } \\
\text { NA }\end{array}$ & $\begin{array}{l}\text { AMI without } \\
\text { Marijuana: } \\
27\end{array}$ & $\begin{array}{l}\text { AMI without } \\
\text { Marijuana: } \\
\text { NA }\end{array}$ & $\begin{array}{l}\text { AMI without } \\
\text { Marijuana: } \\
32\end{array}$ & $\begin{array}{l}\text { AMI without } \\
\text { Marijuana: } 57\end{array}$ & $\begin{array}{l}\text { AMI without } \\
\text { Marijuana: } 41\end{array}$ \\
\hline & $\begin{array}{l}\text { AMI with } \\
\text { Marijuana: } 47.2\end{array}$ & $\begin{array}{l}\text { AMI with } \\
\text { Marijuana: } \\
76\end{array}$ & $\begin{array}{l}\text { AMI with } \\
\text { Marijuana: NA }\end{array}$ & $\begin{array}{l}\text { AMI with } \\
\text { Marijuana: } \\
\text { NA }\end{array}$ & $\begin{array}{l}\text { AMI with } \\
\text { Marijuana: } \\
59\end{array}$ & $\begin{array}{l}\text { AMI with } \\
\text { Marijuana: } \\
\text { NA }\end{array}$ & $\begin{array}{l}\text { AMI with } \\
\text { Marijuana: } \\
19\end{array}$ & $\begin{array}{l}\text { AMI with } \\
\text { Marijuana: } 53\end{array}$ & $\begin{array}{l}\text { AMI with } \\
\text { Marijuana: } 43\end{array}$ \\
\hline \multirow{2}{*}{$\begin{array}{l}\text { Kenneth et } \\
\text { al. [12] }\end{array}$} & $\begin{array}{l}\text { AMI without } \\
\text { Marijuana: } 62.0 \\
\pm 12.3\end{array}$ & $\begin{array}{l}\text { AMI without } \\
\text { Marijuana: } \\
68\end{array}$ & $\begin{array}{l}\text { AMI without } \\
\text { Marijuana: } 27.3 \\
\pm 5.2\end{array}$ & $\begin{array}{l}\text { AMI without } \\
\text { Marijuana: } \\
\text { NA }\end{array}$ & $\begin{array}{l}\text { AMI without } \\
\text { Marijuana: } \\
32\end{array}$ & $\begin{array}{l}\text { AMI without } \\
\text { Marijuana: } \\
\text { NA }\end{array}$ & $\begin{array}{l}\text { AMI without } \\
\text { Marijuana: } \\
21\end{array}$ & $\begin{array}{l}\text { AMI without } \\
\text { Marijuana: } 45\end{array}$ & $\begin{array}{l}\text { AMI without } \\
\text { Marijuana: } \\
\text { NA }\end{array}$ \\
\hline & $\begin{array}{l}\text { AMI with } \\
\text { Marijuana: } 42.6 \\
\pm 8.8\end{array}$ & $\begin{array}{l}\text { AMl with } \\
\text { Marijuana: } \\
94\end{array}$ & $\begin{array}{l}\text { AMI with } \\
\text { Marijuana: } 27.8 \\
\pm 5.3\end{array}$ & $\begin{array}{l}\text { AMI with } \\
\text { Marijuana: } \\
\text { NA }\end{array}$ & $\begin{array}{l}\text { AMI with } \\
\text { Marijuana: } \\
77\end{array}$ & $\begin{array}{l}\text { AMI with } \\
\text { Marijuana: } \\
\text { NA }\end{array}$ & AMI with & AMI with & $\begin{array}{l}\text { AMI with } \\
\text { Marijuana: } \\
\text { NA }\end{array}$ \\
\hline
\end{tabular}

\section{TABLE 2: Baseline characteristics of patients included in selected studies}

SD: standard deviation; BMI: body mass index; AMI: acute myocardial infarction; NA: not available

\section{Outcomes}

Desai et al. [9] evaluated that the odds of all-cause in-hospital mortality were not significantly increased in the AMI with marijuana group as compared to the AMI without marijuana group when adjusted for age, race, the length of stay, the median house of income in the zip code, an indicator of sex, hospital bed size, smoking, and cocaine abuse (adjusted OR: 0.742, CI: 0.693$0.795, p<0.001$ ). The mean length of stay (in days; $4.7 \pm 5.9$ vs. $5.6 \pm 8.0$ ) and the total hospital charges $(\$ 76,272.23$ vs. $\$ 85,702.22)$ were lower in the AMI with marijuana group $(p<0.001)$.

A study conducted by Frost et al. [11] found that compared to the marijuana nonusers, the 
mortality rate was $29 \%$ higher among the marijuana users, but this did not reach statistical significance (95\% CI, 0.81-2.05, $p=0.28$ ).

In the study of Johnson-Sasso et al. [10], there was no association between marijuana use and the primary outcome $(p=0.53)$. The in-hospital mortality rate was significantly lower in the marijuana users compared to the nonusers (OR: 0.79, $p=0.016)$. Apart from the mortality benefit, marijuana users were significantly less likely to experience shock (OR: $0.74, p=0.001)$, or require an intraaortic balloon pump placement (IABP; OR: 0.80, $p=0.03$ ) following AMI. However, marijuana users were more likely to be placed on mechanical ventilation (OR: 1.19, $p$ $=0.004)$.

Kenneth et al. [12] discovered that marijuana users had three-fold higher mortality in comparison to the nonusers after being adjusted for age and sex, and in fully adjusted models. Compared with the nonusers, the hazard ratios for marijuana usage less than weekly and weekly or more were 2.5 (95\% CI, 0.9-7.3), and 4.2 (95\% CI, 1.2-14.3), respectively. For cardiovascular mortality and non-cardiovascular mortality, the age- and sex-adjusted hazard ratios with any use were 1.9 (95\% CI, 0.6-6.3), and 4.9 (95\% CI, 1.6-14.7), respectively. In the same study, while comparing 42 marijuana users and 42 other patients matched on propensity scores, there were six deaths among marijuana users and one among non-users (log-rank $p=0.06)$.

Besides, in a study conducted by Vin-Raviv et al. [13] among cancer patients $(n=387,608)$, odds of in-hospital mortality was found to be significantly reduced among marijuana users compared with non-users (OR: 0.44, 95\% CI: 0.35-0.55). In the same study, they also established that marijuana use was associated with significantly reduced odds of heart failure and cardiac disease compared with non-users.

\section{Discussion}

Marijuana is becoming increasingly available to the general population after its legalization in several states of the USA. As both medical and recreational use of marijuana is increasing, the knowledge and attitude among healthcare workers and patients about marijuana are important. Both healthcare providers and patients must carefully balance the anticipated benefits and the established health risks.

In our review, two out of four studies are cohort studies, and both studies found that marijuana use was associated with higher folds of mortality. It is in contrast with two retrospective studies that demonstrated decreased all-cause mortality following MI. Since retrospective studies cannot establish a causal relationship, at this point, we cannot conclude if marijuana is beneficial or harmful, which remains a major limitation of our review. Nevertheless, the results of our review should not be neglected. Further large cohort study with sufficient follow-up time is required to establish the causal relationship between marijuana use and the outcomes following MI. Additionally, clinical trials on supplementation of medical marijuana in MI patients can be done to observe the direct effect. But conducting a randomized controlled trial (RCT) by supplementing medical marijuana will raise an ethical issue. Hence, RCT seems to be impractical at this point in time.

The major limitations of the included studies are represented in Table 3. All the studies have included the patients with MI who were admitted to the hospital. Hence, the possibility of unmeasured or residual confounding was not ruled out in all four studies. In the retrospective studies of Desai et al. [9] and Johnson-Sasso et al. [10], patients were not followed up to evaluate the long-term outcomes of marijuana in MI patients. 


\section{Cureus}

\section{Study Major limitations}

Desai et Only studied in-hospital odds of mortality, which leaves out outpatients or post-discharge odds of mortality in al. [9] Ml patients

Frost et were on some medications before sustaining MI, so they might have received secondary prevention

al. [11] measures in a manner unrelated to marijuana use; the study was based on self-reported marijuana use, so there may be some exposure misclassification

Johnson-

Angiograms, laboratory tests, medications taken pre- or post-MI, and vital signs on admission were not

Sasso et available; no post-discharge data including long-term mortality and readmissions; the route, amount and

al. [10]

frequency of marijuana use in each patient could not be determined, so a dose-response effect could not be established

Kenneth The number of marijuana smokers was relatively small; follow-up was limited to approximately 4 years; could et al. [12] not prove cause and effect relationship

\section{TABLE 3: Major limitations of the study}

MI: Myocardial infarction

The present work is, to our best knowledge, the most comprehensive systematic review of the latest four studies, allowing a direct review of marijuana use and outcomes in patients with MI. Despite a relatively small number of the available original studies, the number of patients included in these studies was large.

\section{Conclusions}

To conclude, this review has found that in-hospital mortality in patients with MI was significantly reduced among marijuana users compared with non-users in retrospective studies but not in cohort studies. However, we could not conclude whether the outcomes of retrospective studies occurred due to a direct causal relationship or by chance. Therefore, additional large cohort studies and clinical trials are required to establish the relationship.

\section{Additional Information}

\section{Disclosures}

Conflicts of interest: In compliance with the ICMJE uniform disclosure form, all authors declare the following: Payment/services info: All authors have declared that no financial support was received from any organization for the submitted work. Financial relationships: All authors have declared that they have no financial relationships at present or within the previous three years with any organizations that might have an interest in the submitted work. Other relationships: All authors have declared that there are no other relationships or activities that could appear to have influenced the submitted work.

\section{References}

1. Hasin DS, Saha TD, Kerridge BT, et al.: Prevalence of marijuana use disorders in the United States between 2001-2002 and 2012-2013. JAMA psychiatry. 2015, 72:1235-42.

10.1001/jamapsychiatry.2015.1858 
2. Iversen LL: Medical uses of marijuana. Nature. 1993, 365:12-3. 10.1038/365012a0

3. Pacher P, Batkai S, Kunos G: The endocannabinoid system as an emerging target of pharmacotherapy. Pharmacol Rev. 2006, 58:389-462. 10.1124/pr.58.3.2

4. Quercioli A, Pataky Z, Vincenti G, et al.: Elevated endocannabinoid plasma levels are associated with coronary circulatory dysfunction in obesity. Eur Heart J. 2011, 32:1369-78. 10.1093/eurheartj/ehr029

5. Rajesh M, Batkai S, Kechrid M, et al.: Cannabinoid 1 receptor promotes cardiac dysfunction, oxidative stress, inflammation, and fibrosis in diabetic cardiomyopathy. Diabetes. 2012, 61:716-27. 10.2337/db11-0477

6. Pacher P, Mechoulam R: Is lipid signaling through cannabinoid 2 receptors part of a protective system?. Prog Lipid Res. 2011, 50:193-211. 10.1016/j.plipres.2011.01.001

7. Steffens S, Veillard NR, Arnaud C, et al.: Low dose oral cannabinoid therapy reduces progression of atherosclerosis in mice. Nature. 2005, 434:782-6. 10.1038/nature03389

8. Franz CA, Frishman WH: Marijuana use and cardiovascular disease . Cardiol Rev. 2016, 24:15862. 10.1097/CRD.0000000000000103

9. Desai R, Patel U, Sharma S, et al.: Recreational marijuana use and acute myocardial infarction: insights from nationwide inpatient sample in the United States. Cureus. 2017, 9:1816. 10.7759/cureus.1816

10. Johnson-Sasso CP, Tompkins C, Kao DP, et al.: Marijuana use and short-term outcomes in patients hospitalized for acute myocardial infarction. PLoS ONE. 2018, 13:0199705. 10.1371/journal.pone.0199705

11. Frost L, Mostofsky E, Rosenbloom JI, et al.: Marijuana use and long-term mortality among survivors of acute myocardial infarction. Am Heart J. 2013, 165:170-5. 10.1016/j.ahj.2012.11.007

12. Mukamal KJ, Maclure M, Muller JE, et al.: An exploratory prospective study of marijuana use and mortality following acute myocardial infarction. Am Heart J. 2008, 155:465-70. 10.1016/j.ahj.2007.10.049

13. Vin-Raviv N, Akinyemiju T, Meng Q, et al.: Marijuana use and inpatient outcomes among hospitalized patients: analysis of the nationwide inpatient sample database. Cancer Med. 2017, 6:320-9. 10.1002/cam4.968 